\title{
On the Future of Regional Geography
}

\section{Gerald Wood, Duisburg}

\section{Introduction}

This essay is the revised and expanded manuscript of a paper given in January 1999 on the occasion of the ceremonies to mark the centenary of the Institute of Geography in Würzburg. The task of this paper was to reflect upon the future of regional geography. In view of the peripheral position regional geography occupies in the German-speaking countries such a task is not an insignificant challenge. In how far can regional geography be looked upon as an up-to-date academic activity today, after having been given up as the paradigmatic cornerstone of the discipline in the course of the modernisation in the 60's and 70's and after having played a peripheral role in the discipline ever since? EUGEN WIRTH (1998) recently submitted his proposal, by suggesting the theory of action as a possible starting point for scientific regional research.

This paper goes about addressing the problem in a different fashion, by first identifying present socio-spatial developments which might serve as starting points for a modern, competitive regional geography. The next step is to try and spell out the conditions which regional geography needs to meet in order to be regarded as an upto-date research task. These prerequisites are taken from the modern conceptions of science. Finally, on the basis of these considerations, possible research issues of a reconstituted regional geography are discussed.

Some of these reflections are informed by or build on a recent paper by SUSAN HANSON (1999) who discusses the rift that took place in human geography during the «quantitative revolution» and which now seems to be on the wane. HANSON highlights signs of a reconnection between the two large strands in human geography which deal with nature-society, the specific («idiographic») on the one hand and with society-space, generalizable knowledge (quantification and abstraction) etc. on the other. One of the most stimulating observations HANSON (1999: 137) arrives at is her analysis of the reasons behind that reconnection: It is the structuralist notion of the fact that key concepts in human geography, like nature, society and space, are all to some degree socially constructed. This recognition has «eroded the boundary between nature-society and societyspace» and therefore provides a valuable starting-point for the key concern of this paper: to show that regional geography can be considered a feasible academic endeavour.

\section{Historical background}

If one attempts to look into the future as is the case in this paper with regard to regional geography, then it is advisable to first take a look back into history. Such an approach offers two possible advantages. It may reduce the danger of repeatedly inventing the wheel and it can help to prevent hasty proclamations about future prospects of the discipline. For this reason this contribution does not venture to present a blueprint for the future of regional geography. Rather, it attempts to outline some possibilities for regional research, informed by modern conceptions of science and inspired by present sociospatial developments.

According to Hermann Lautensach (1933), by the early 30 s regional geography had developed to become the "core» of the discipline. Amongst others, HetrNer (1927: 122ff) had by then successfully codified regional geography so that it occupied a central position within geography. This was so mainly because it was assumed that regional geography had an overarching, integrating role to play in the discipline (PLEwE 1952). This view was widely accepted amongst geographers at the time and it was challenged only in the $60 \mathrm{~s}$ and 70 s when the spread of an analytical-pragmatic and nomothetic paradigm reached the community of geographers. In Germany, where the critical appraisal of the status of regional geography commenced later than in the English speaking countries, the Geographical Conference of 1969 which took place in Kiel became a major watershed for the discipline. A group of young geographers, many of whom were students, challenged the received wisdom of the establishment. In essence, they accused the advocates of regional geography of unscientific working practices because to them the latter only gathered facts and emphasised the «individuality» of spatial units, the regions. The critics whose discourse on the philosophy of science was informed by logical positivism (cf. HARVEY 1969) and critical rationalism pointed out that regional geography was lacking a theoretical foundation on which an explanation of empirical facts could be grounded. Part of the criticism was directed at what the critics regarded to be a pre-modern frame of mind of regional geographers - who saw the world as a well-ordered mosaic which the regional geographer's «art» had to put together -, at the implicit geo-determinism and at the exclusion of social practices from academic work.

By the late 60s early 70s a new discourse had asserted itself in geography which was to point the way ahead for the next decades. As a consequence, from then on regional geography only played a minor role until the 
recent past. This minor role, however, mainly expressed itself in the low esteem that regional geography enjoyed in the eyes of those geographers whose frame of mind was shaped by an understanding of academic work deeply rooted in logical positivism and critical rationalism. This state of affairs was sharply contrasted by the fact that at the same time many regional studies were being published. Thus, it is patently impossible to infer from the (then) dominant paradigmatic understanding of the discipline the performance and the relevance of regional geography in the wider society - and vice versa.

The peripheral position of regional geography in academia during the 70's did not change, despite the attempts of individuals to put it on a (new) epistemological foundation. WIRTH (1978) in his endeavour to resurrect regional geography, for example, takes up certain key elements of critical rationalism as developed by POPPER. According to WIRTH regional geography should be treated as a historical science which deduces singular events from general laws (which in the case of regional geography can be taken from the systematic fields of geography) and special antecedent conditions (which result from the unique situation under investigation). This approach will not only render a description but also provide the academic with an explanation of empirical phenomena. This view challenged other academics, notably G. Bahrenberg (1979). The dispute that evolved between the two antagonists did not, however, have a widespread impact. The fact that a broad discussion on the significance of regional geography did not take place at the time may have its roots in the repercussions of the «quantitative and theoretical revolution» of the 60's and 70's as well as in the growing inner diversity of the discipline as a whole.

This situation gradually changed in the 80's. In Germany, for instance, Popp (1983), Heinritz (1987), POHL (1986) and others offered a hermeneutical understanding of regional geography. In the English-speaking countries, in the Netherlands and in France regional geography experienced a certain renaissance as a social scientific «new regional geography» (cf. GILBERT 1988, Holmen 1995, Wood 1996). The situation in the German-speaking countries in the recent past and at present is characterised by the absence of a theoretical, conceptional debate which can be observed in a number of other countries, most notably in England and the United States, in France and in the Netherlands (cf., for instance, Bassand \& Guindani 1983, Claval 1981, 1998 a, 1998 b, RAFFESTIN 1982, HANSON 1999, Villeneuve 1986, Johnston, Hauer \& Hoekveld 1990 a, b, JOHNSTON 1990, ENTRIKIN 1994, SAYER 1989, Pudup 1988, Swyngedouw 1989, Nir 1990; Harloe, Pickvance \& URry 1990, Cooke 1989). This state of affairs appears to be paradoxical because there is, on the one hand, a constant flow of regional studies which seem to have a stable market, yet, on the other, a reflection of the epistemological and societal foundations of regional geography is left to others. This situation can be explained by several factors. First of all, there are evident symptoms of fatigue which are caused by the debates taking place within the discipline in the wake of the «scientific revolution» of the 60's and 70's. Secondly, these debates caused a «migration» to other fields of interest within the discipline. And lastly, it seems that after the epistemological fundamental criticism which was levelled at regional geography there is now a widespread essential helplessness as to which (epistemological) perspective can help to «modernise» regional geography.

\section{Future perspectives of Regional Geography}

Despite the demise of regional geography in the past and the current speechlessness of most academics (apart from a few exceptions, cf. WIRTH 1998) there are signs that in the future there may be a countercurrent. The crucial question that needs to be addressed in the context of a redefined regional geography is whether it can be set up as a research task which manages to go beyond the deplored unscientific working practices of the past when it was the compilation of material or the more or less intuitive and unsystematic explanation that occupied geographers' minds and not so much a theoretically informed reasoning typical of modern conceptions of science. Before dealing with this latter line of argument in greater detail, however, the next issue to be looked into are some social trends which suggest that regional geography can indeed be regarded as a research task that has a future. Without claiming to be comprehensive, the following trends can be discerned (cf. Blotevogel 1996 and Wood 1996):

1. On the one hand there are processes of spatial restructuring, i.e. processes of regionalization, taking place on different spatial scales and in different social subsystems (economy, politics). For instance, we recognise an interplay of unifying global and differentiating regional trends within which social change is currently taking shape. Inherent to some of these processes is a great dynamism which is likely to cause further changes in the spatial organisation of society.

In the sphere of politics, for instance, it is expected that the intensifying process of European integration (and the realisation of the principle of subsidiarity within the EU) will eclipse the importance of the national level on the one hand and enhance the status of the supra-national and the regional level on the other. An indicator of this trend is the establishment of the committee of the regions in the EU but also the attempt of the EU to gain a direct role in the development of the regions by devising the conditions for aid programmes accordingly. 
With regard to planning policy the complexity of structural change exercises excessive demands on central (state) agencies. This is why these agencies (in their own interest) tend to decentralise decisions, responsibilities and the solution of problems. At the same time, the complexity of the problems and the need to process an ever growing amount of information exceeds the capacities of local authorities so that there is a growing willingness «from below» for cooperation between local authorities, i.e. on a regional level (cf. Priebs 1998).

2. In this context it is important to point out that the «regionalization of ways of life» is also spreading because more and more people (have to) live and work «regionally», i.e. across the boundaries of local authorities and previous spatial units of planning. This can either be the result of forced mobility (due to deficits of local labour markets) or of changed individual preferences (with regard to consumption, leisure and educational activities, for instance).

3. On the other hand we can observe an enhancement of the regional level in the context of socio-cultural developments which expresses itself in the revival of regional socio-cultural activities, such as «Heimat» or (local) history societies.

4. Closely connected with these trends is a tendency towards a deliberate as well as an accidental production and reproduction of «regional identities». The main purpose of that exercise, which can be observed in the sphere of planning policies in Germany as well as in the separatist discourse in the Basque region or in Corsica, is to wield greater political power over social processes.

5. With regard to ecological debates the discussion centring on the consequences of global-scale pollution suggests an increased importance of the regional level. In view of the world-wide circulation of raw materials and commodities with its ecologically harmful outcomes there is a growing call for making ecologically detrimental effects spatially attributable by, for instance, establishing regional economic cycles. This is one of the reasons why facilities such as waste disposal sites for far-away agglomerations have come under increased criticism.

These tendencies of socio-spatial development need to be looked into more closely by means of a critical academic reflection. This is all the more important as it is not entirely clear whether the discussed phenomena are «real» or whether they are just fashionable trends of the current debate in the spatial sciences and in regional political discourse which will not stand the test of empirical inquiry. Thus, the mentioned forms of spatial structuring and restructuring, their social and constructivist meanings need to be contemplated by academics who see themselves as critical commentators of social trends - and discussed in the political public. This is the most important and persuasive argument for and justification of an up-to-date regional geography.

The important issue here is not so much which specific philosophy of science the individual academic might call his or her own. Regardless of whether one considers oneself a neo-positivist, a critical theorist or a supporter of hermeneutics: this form of regional research needs to be a methodically controlled generation of knowledge (Blotevogel 1996). Of course, different understandings of what science is (or should be) about rest upon different epistemological and methodological assumptions, for instance on contrasting concepts of knowledge or causality. Quite clearly, there is not the one way of scientific enlightenment. HANSON (1999: 136) highlights this when she observes that now there is «a greater willingness to acknowledge complexity and to engage multiple approaches to understand that complexity. There is now a greater acceptance of the notion that people create knowledge rather than discovering objective truths $[\ldots]$ and that taking advantage of what is useful in each of a number of approaches can yield greater understanding than does adhering only to one.» At the same time, however, there also cannot be an «anything goes», that is a regional geography without theory. Because whatever the differences between the aforementioned schools of thought may be, they do have at least three things in common which distinguish them from traditional regional geography: the explicit reference to theory, the reciprocal relationship between theory and empirical evidence and the resultant development of theory. It is this which characterises competitive research. Of course, it needs to be stressed in this context that collecting, processing and disseminating spatial data will always be an indispensable task for a regional geographer. This, however, is not research but a preliminary stage of research.

The definition of competitive research which was suggested above is incomplete as it does not reflect the social contexts in which research agendas are being drawn up or in which research results are being applied. It would be a self-deception to believe that regional geography can do without an explicit reference to or incorporation of normative issues. Research agendas and academic interests are no natural phenomena nor are they in any way given by «landscapes» or «regions» or whatever. It is the society that determines research agendas and that applies research results. This is why the academic disciplines which are an intrinsic part of society need to reflect the origin and the legitimacy of research topics and the use of research results.

This line of argument is a necessary but not yet a sufficient condition for a regional geography which regards itself to be competitive research. What is lacking is a definition of the actual questions to be raised and problems to be tackled by regional geographers. A systematic discussion of this issue has not taken place yet, espe- 
cially in the German-speaking countries. The following section of this paper will try to address this question by tentatively developing some lines of inquiry which seem worthy of being pursued. This will be done with reference to the above mentioned current social trends.

\section{Research issues}

\subsection{Tendencies of economic and political restructuring}

Starting with the observation that there are at present significant trends of spatial restructuring taking place in different social sub-systems (politics, economy) which are frequently referred to by the terms «globalisation» or «regionalization» (or, alternatively, by «global unification» and «regional diversity») and which are said to have far-reaching consequences, regional geography needs to analyse the shape, causes and the effects of such processes of restructuring in the different social sub-systems. In the English and the French-speaking countries (cf. GILBERT 1988, for a recent overview of the situation in France cf. Claval 1998.2) proponents of a political-economy approach (as part of a «new» or «reconstituted regional geography»), for instance, investigate the dialectical relationship between specific regional developments and the overall political and economic structure of society, set against the background of global processes of economic restructuring. The basic premise on which this edifice of ideas rests is the assumption that structural change does not take place in a vacuum, but in a specific socio-spatial, historically rooted context («layer of history») which plays an important role as to the ways in which (global) change is taking shape on the ground. Conversely, so the argument goes, the developments on the ground have an input into the system. Thus, both levels are closely connected to one another and form a complementary set of issues to be addressed when looking at structural change. Another important point to make is that according to this school of thought «regions» are an integral part of society. This is why the latter will not simply «vanish» as societies modernise but will continue to exist because spatial differences are regarded to be an essential element of society (in the sense of social relations as spatially and temporally contingent phenomena). It would, therefore, be an interesting and deserving research project to test this hypothesis empirically.

With regard to differences in discourse tradition the overview provided by CLAVAL (1998.2) - as VAN DER WUSTEN (1998) points out - shows that the French debate on globalisation displays a sensitivity to (perceived) Anglo-American hegemony, a fact which is accentuated by different words used for the English term globalisation: "globalisation, which is mainly used for environmental problems, and mondialisation, which is associated with the economic transformations of the contemporary world» (Claval 1998.2: 69). Although there seems to be a convergence of language usage lately, the French «have strongly defended the national heritage also in geography» (VAN DER WUSTEN 1998: 2). Notwithstanding these differences there has been a noticeable French influence on the ways in which the processes of globalisation are theorised in the Englishspeaking countries. For instance, there has been a strong input of the «regulationist school» which seeks a theoretical interpretation of processes of globalisation in the spheres of economics and politics (cf. Aglierta 1976).

In the context of the «globalisation» debate one of the main questions to be tackled - according to OSSENBRÜGGE - will be in how far the future development of the space economy will indeed be characterised by the dialectical relationship between global unification and regional diversity (This line of thought does not refer to other printed sources but is based on discussions the author had with colleagues, notably with JÜRGEN Ossenbrügge, Rainer Danielzyk, Ilse Helbrecht and JÜRGEN POHL who I wish to thank for their inspiration.). In this context it is important to stress that the term diversity denotes a fragmentation as well as the specific capacity for creativity and innovation which are both necessary for the reproduction of global capitalism. If diversity is regarded to be a resource then the question will have to be addressed as to whether the integration into the global context does not exhaust this asset so that the dialectical relationship between globalisation and regionalization does have a long-term self negating tendency and therefore needs to be seen as a temporary model of development.

For HANSON (1999: 139) dealing with processes of globalisation, or rather, with the tension that exists between the global and the local, provides an opportunity to rethink the issue as to what distinguishes «adequate» theory: «No longer abstract as it once was, theory can now be grounded more readily in the complexities of places and their connections with processes at a variety of scales.» Thus, the globalisation debate can help to modernise the ways in which (regional) geographers theorise and thus make sense of their empirical observations.

\subsection{Regional (socio-)culture}

Another point of departure for regional geography refers to the increased importance of the regional level in the sphere of socio-cultural developments (which can be inferred from several observations, such as the revival of «Heimat» or (local) history societies, for instance). It may appear to be anachronistic to probe the relevance of regional culture(s) because one could - with regard to the examples mentioned - argue that regional culture and the «region» are merely reminiscences of an era when people were still spatially «embedded» (as opposed to the late modern experience according to 
GidDENS 1991 or WeRLEN 1995), had a strong local and/or regional awareness as part of their daily lives and did not go beyond the confines of their local/regional universe in their thinking (at least at most levels of society). Thus, which relevance can regional culture have in an era of unprecedented mobility (at least for those who are fortunate enough to live in the rich countries), of information networks which span the globe and which allow us to participate in far away events as easily as we partake in the things happening around us? And, lastly, what is the significance of regional culture when it is lifestyle orientation which directs our ways of thinking and feeling much more than «regional identity»?

And yet, one could argue that despite this argument the regional level does have an important socio-cultural meaning in our age. The more people experience the uniforming and limiting effects of global economic, social, political and socio-cultural developments at the lo$\mathrm{cal}$ and regional levels the more will these levels gain in importance as a counterbalance, maybe even as a counter-force which challenges the uniforming trends of globalisation. With regard to more recent socio-cultural developments one can interpret the rediscovery of the «regionally specific» as such a response. The fact that the control of social developments is increasingly shifted to higher levels (of scale) generates a response from below: regional awareness places itself on the (political) agenda. Or, as Claval (1998.1: 159) sees it, «The crisis in feelings of belonging to a nation thus makes regional identity fashionable again.»

At the same time the changes that globalisation effects in the prevailing conditions of social control may hold in store opportunities for the local and regional levels because the diminishing (eclipsing?) role of the nation state due to supra-state arrangements may lead to a relative strengthening of other (spatial) levels, i.e. the regional and supra-national vis-á-vis the state levels.

The «region», according to this understanding, can be seen in two rather different ways. On the one hand it can serve as a basis for justifying particularisms and local vendettas (Claval 1998.1: 160). This issue is usually associated with regionalist ideology and thus an expression of the «regional» being taken advantage of by the political system (cf. PIEPER 1987). It will be taken up further down. On the other hand the region can be seen as a source of meaning and significance in a world which is increasingly getting incomprehensible to a growing number of people, despite - or due to - the fact that many people «know» more of the world through the media and their own travel-encounters. These reflections on the socio-cultural relevance of the region seem to be another suitable starting-point for a revised regional geography.

\subsection{Regional development and socio-culture}

The discussed developments in the sphere of politics, the economy and (regional) socio-culture could, and to my mind, should also be seen in context (The following considerations are based on a paper by DANIELZYK \& WooD, submitted to European Planning Studies and at present refereed.). For instance, there has been a growing recognition of the importance of cultural aspects explaining regional development within regional research in German-speaking countries over the recent past (cf. HäUSSERMANN \& SiEBEL 1993). This trend reflects the realisation that «hard (locational) factors» such as economic structures, labour costs, property prices etc. - alone cannot explain the performance of regions. As a consequence, cultural aspects, such as «identities», «mentalities», «milieus», political cultures and the like have been increasingly incorporated into theorising the «success» or «failure» of individual regions (for an overview cf. KRÄTKE 1995). On a deeper level this trend can be seen as a reformulation of the essential question on the relationship between culture and economic development, which MAX WeBER (1973, orig. 1905) addressed when he traced the origins of capitalism back to the ascetic ethics of certain movements within Protestantism.

However, as yet there are neither many studies which empirically test the presumed relationship between cultural and economic developments on the regional level nor is there a well developed, consistent theoretical approach dealing with that relationship. Thus, there is much scope for future research in this field.

\subsection{Production and reproduction of «regional identities»}

With regard to the above mentioned production and reproduction of «regional identities» by the elites of the economic and the political system as well as the cultural industries - which can be a deliberate or an accidental act - regional geography needs to address the issues, aims and consequences involved in such a utilisation of the «regional». Primary objects of study would be the spatially codified artefacts of social practice, i.e. the specific culturally encoded «regional identities». These «regional identities» need to be deconstructed in order to disclose the specific view of the world they propose and hence, the intentions of those who propagate them. There are various reasons for looking into these manifestations of social practice. To begin with, doing so may enhance our understanding of the ways in which social processes shape the socio-culture. Secondly, the deconstruction of the strategy to produce and reproduce «regional identities» - and thereby exercise power over the lifeworld - demonstrates that (any) socially codified meaning is not an intransmutable given. It challenges the views it deconstructs and can thereby help to open up avenues for criticism and social change. 
In order to illustrate this train of thought a fairly recent example taken from a German weekly newspaper, «Die Zeit», shall now be discussed. A few years ago the prime minister of Saxony, KURT BIEDENKOPF («King Kurt» as he is called in Saxony) in a newspaper interview emphasised that the people of Saxony had to prepare themselves for a prolonged period during which the income discrepancies between the «old» and the «new» German states («Länder») would persist. He suggested that his fellow citizens should therefore try and deem values other than materialistic ones worthy of their consideration, such as the "regional identity» of the Saxons. Regional identity was declared a substitute for an equal share in the material prosperity of an affluent society. Doing so meant that fundamental questions were raised which affect the principle of equality laid down in the German constitution as much as the pivotal orientation in spatial planning after the Second World War, i.e. the creation of equal living conditions in all parts of the country.

\subsection{The (ecological) problems of late modern societies - from a human ecology point of view}

So far this paper mainly addressed issues of a more or less social scientific orientation. This may be surprising as the main reason for the success of regional geography as the «core» of the discipline was its integration of physical and human geography in the past. Will a social scientific understanding of regional geography therefore lead to a loss of the disciplinary unity? It is of course legitimate to raise this issue but it is futile to hope and define regional geography as an up-to-date science by asserting the unity of the discipline. Because as a normative view it may help to generate a feeling of belonging amongst geographers, but it does not answer the question as to how regional geography can be defined as a competitive science which holds its ground against the neighbouring disciplines. It seems that an answer to that question - which also holds out promising joint research issues for physical and human geography - can best be derived from the ecology debate or from the human ecology paradigm (cf. WEICHHART 1994, ZiERHOFER 1997).

One of the most distinguishing features of the human ecology paradigm is its attempt to overcome the occidental intellectual duality between nature/matter on the one hand and man/culture/society on the other. Human ecology postulates a deviation from the mechanistic view of the world and of man in the tradition of $\mathrm{R}$. DESCARTES and I. NewTON and propagates a new synthesising view. It conceptualises society and economy (the latter as a social sub-system) as integral parts of nature, and thus both have to recognise the limits set by the natural environment. The regulating principle which governs the interplay of the constituent elements of nature is «sustainability». Sustainability needs to be seen not only in its traditional sense as a limitation of the consumption of resources (which took its origin in forestry and regulated the amount of wood being cut down). Sustainability also needs to be understood in a more comprehensive long-lasting conservation of nature as a productive force (BUSCH-LÜTY 1992). As a consequence of such a view the ways in which human beings treat their natural and social environments move centre stage. In a similarly fundamental way, the human ecology paradigm entails a reappraisal of the traditional separation of the natural sciences on the one hand and the social sciences as well as the humanities on the other. It is because of that division that «nature» was lost out of sight in the social sciences and in the humanities and that the natural sciences failed to recognise the social and the intellectual meaning of «nature» (WEHLING 1995).

This discussion links in with the debate on the development of geography as an academic discipline. In the past there has been a three-way split within geography: the ongoing separation of human and physical geography and the «rift» in human geography between a nature-society and a society-space strand (cf. HANSON 1999). This split in human geography marked the disintegration of the leading role that regional geography (the geography of the specific, idiographic) played prior to the «quantitative revolution» and the advent of spatial analysis as the hegemonic discourse at the time. One consequence of that split was the move away from place toward space which entailed the expatriation of nature in the discourse of spatial analysis. As HANSON (1999: 134) puts it, "The creation of space without nature is key because those leading the quantitative revolution believed that equating the geo in geography with the isotropic plane was essential to making geography a respectable scientific discipline, one able to develop geographic generalizations.» Doing so, however, meant that for several decades those who set the tone regarded the exclusion of nature from (human) geography an inevitable step if the discipline was to discharge its unscientific image. It seems to me that only by overcoming the fear of environmental determinism which, among others, was behind this development, will there be a realistic chance for geographers to help and come to grips with some of the core issues of our age and with the schisms in our discipline (cf. HANSON 1999).

The concern for the relationship between nature/environment and man in human ecology has several reasons. One is the above-mentioned problematic split in our occidental thinking and the division between and within the academic disciplines that went along. The second, equally important reason is the realisation of the significance of ecological and other man-made problems in late modern societies (BECK 1996). And lastly, it is the failure (crisis) of modern academic disciplines to offer post-modern societies an orientation that has stimulated the human ecology debate. 
It is at this stage not at all clear whether a human ecology society-space paradigm will prove to be an adequate basis for regional research. On the other hand, the traditional man-nature paradigm is clearly outdated and a more viable alternative needs to be put in its place. If regional geographers wish to do so by means of a human ecology approach then they will need to resolve a number of open and problematic issues.

To begin with, human ecology is confronted with the general problem of making value judgements in science. Who is to determine the contents and the validity/ viability of a conception of science which is explicitly rooted in a normative foundation? Everybody for herself? The «bishops» of the discipline or the nonconformists who due to their status may not have a strong impact however? How viable is an ecological ethical principle as a point of departure and reference for a science? Does a normative approach not lead to intolerance because it shows a tendency to confirm preconceived value judgements?

On an epistemological level there is the problem of combining very different views of the world as they are representative of the different perspectives of the individual sciences. Natural scientists tend to regard the world mainly as a material world that obeys natural laws. This view is very different to that of social scientists who expatriated «space» and the material world in general from the structure of their theories. Some critics, like Gerhard Hard (1994), therefore, conclude that these different perspectives are incompatible and that any attempt to form an integrative environmental science will only end up in «folk science».

My own view is that this conclusion although it cannot be denied may have a defeatist effect. I would contend that such a view underestimates the ability of scientists to reflect their own thinking (and the assumptions on which that thinking rests). There are several reasons why regional geography should get (more) involved in the human ecology debate. The most convincing is a normative one: bearing in mind the global man-made problems that the sciences have helped to create or aggravate, the role of the sciences or rather the self-perception of academics can no longer be the innocent modernist belief that scientific-technical solutions will ameliorate the problems of mankind. What is needed instead is a critical approach which is reflexive in the sense of Critical Theory and which at the same time takes as its theme the central issues of the man-environment relationship. Such an orientation could help to open up the different forms of scientific discourse to each other as well as to the outside, and it could enhance the societal standing of the disciplines involved, thereby improving the prospects of the latter for a continued existence as academic subjects.

\section{Conclusion}

The central aim of this paper was to identify the possible future role of regional geography. Despite the prevailing trend in the German-speaking countries and in view of the renewed interest in regional geography in several other countries there seems to be scope for regional geography to contribute to our understanding of the world. The overall social trends which were discussed can be seen as an important starting point, opening up avenues for progress in the field. Progress, however, can only be achieved if the practitioners of regional geography meet the standards set by modern conceptions of science. Thus, regional geography which is not informed by theory runs the risk of drowning in an ocean of information or of making implicit theoretical and methodological choices (like many of those practising traditional regional geography did). On the other hand, regional geography cannot divorce itself from the empirical world. If it did, it would be likely to become a bloodless Platonic Universe of Ideas, merely producing theories for their own sake.

If regional geography takes on board the challenge of giving up the value-free stance typical of the "old school» and gets involved in social debates instead, then it could contribute to the solution of social problems and may thus improve its authority as a socially relevant academic subject. As LeE (1990:117f) put it, «... regional geography is not merely of analytical significance but of paramount emancipatory importance.»

There are a number of obstacles and pitfalls on the road to a «reconstituted» regional geography though. They result from the different understandings of central issues and concepts («nature», for instance), from incorporating normative issues into science and from having to decide whether or not the importance (renaissance) of key issues is just a fashionable discourse - keeping academics engaged and the flow of research funds goingwhich will not stand empirical validation.

At the same time these challenges can be seen as real opportunities for regional geography as well. Without wanting to gloss over the difficulties lying ahead, addressing the identified issues and taking on the challenges that go along with them is an inevitable choice regional geographers have to make if their discipline is to comply with the demands made by modern conceptions of science. Making that choice will entail dispute, ambiguities etc. but hopefully also the chance of becoming more socially visible and accepted.

\section{Literature Cited}

AglietTA, M. (1976): Régulation et crises du capitalisme. - Paris: Calmann Lévy.

BAHRENBERG, G. (1979): Anmerkungen zu E. Wirths vergeblichem Versuch einer wissenschaftstheoretischen Begründung der Länderkunde. - In: Geographische 
Zeitschrift 67.2: 147-157.

Bassand, M. \& S. Guindani (1983): Maldéveloppement régional et luttes identitaires. - In: Espaces et Sociétés 42: 13-26.

BECK, U. (1996): Weltrisikogesellschaft, Weltöffentlichkeit und globale Subpolitik. Ökologische Fragen im Bezugsrahmen fabrizierter Unsicherheiten. - In: DIEKMANN, A. \& C. JAEGER (ed.): Umweltsoziologie. - = Kölner Zs. f. Soziol. u. Sozialpsychol., Sonderh. 36, Opladen: 119-147.

Blotevogel, H.H. (1996): Aufgaben und Probleme der Regionalen Geographie heute. - In: Berichte zur deutschen Länderkunde 70.1: 11-40.

BusCH-LÜTY, C. (1992): Nachhaltigkeit als Leitbild des Wirtschaftens. - In: BUSCH-LÜTY, C., DÜRR, H.-P. \& H. LANGER (ed.): Ökologisch nachhaltige Entwicklung von Regionen. - = Polit. Ökologie 10, Sonderh. 4, München: 6-12.

Claval, P. (1981): Les géographes et les réalités culturelles. - In: L'Espace Géographique 4: 242-248.

Claval, P. (1998 a): An Introduction to Regional Geography. - Malden, Mass.: Blackwell Publishers.

Claval, P. (1998 b): Globalization and the practice of geography in France. - In: GeoJournal 45.1-2: 69-75.

Cooke, P. (ed.) (1989): Localities. The Changing Face of Urban Britain. - London: Unwin Hyman.

Entrikin, J.N. (1994): Place and Region. - In: Progress in Human Geography 18.2: 227-233.

GidDENS, A. (1991): Modernity and self-identity: self and society in the late modern age. - Stanford: Stanford University Press.

GiLbert, A. (1988): The new regional geography in English and French-speaking countries. - In: Progress in Human Geography 12.2: 208-228.

Hanson, S. (1999): Isms and Schisms: Healing the Rift between the Nature-Society and Space-Society Traditions in Human Geography. - In: Annals of the Association of American Geographers 89.1: 133-143.

HARD, G. (1994): Die Natur, die Stadt und die Ökologie. Reflexionen über «Stadtnatur» und «Stadtökologie«. - In: ERnSTE, H. (ed.): Pathways to human ecology. From observation to commitment. - Bern: 161-180. Harloe, M., Pickvance, C. G., Urry, J. (ed.) (1990): Place, policy and politics: do localities matter? - London: Unwin Hyman.

Harvey, D. (1969): Explanation in Geography. - London: Edward Arnold.

Hauer, J. \& G. Hoekveld (1993): Introduction: Why Regional Human Geography? - In: HAUER, JoOST, Gerard Hoekveld (ed.): Moving Regions. $-=$ Nederlandse Geografische Studies 161, Utrecht: 13-24.

HäussermanN, H. \& W. Siebel (1993): Die Kulturalisierung der Regionalpolitik. - In: Geographische Rundschau 45: 218-223.

HeinRITZ, G. (1987: «Diorama Approach» und «Hermeneutik» - Ansätze einer neuen Regionalen Geographie? - In: HütTEROTH, W.-D. \& H. BeCKeR (ed.): 45.
Deutscher Geographentag Berlin. Tagungsbericht und wissenschaftliche Abhandlungen. - Stuttgart: 149-154. HetTNer, A. (1927): Die Geographie. Ihre Geschichte, ihr Wesen und ihre Methoden. - Breslau: Ferdinand Hirt. Holmen, H. (1995): What's New and What's Regional in the «New Regional Geography»? - In: Geografiska Annaler 77B: 47-63.

JoHNSTON, R. J. (1990): The challenge for regional geography: some proposals for research frontiers. - In: Johnston, R.J., Hauer, J. \& G.A. Hoekveld (eds.): Regional Geography. Current developments and future prospects. - London: 122-139.

Johnston, R.J., Hauer, J. \& G.A. Hoekveld (1990a): Epilogue: towards an agenda for regional geographical research. - In: Johnston, R.J., Hauer, J. \& G.A. Hoekveld (eds.): Regional Geography. Current developments and future prospects. - London: 208-216.

Johnston, R.J., HaUer, J. \& G.A. Hoekveld (1990b): Regional Geography. Current Developments and future prospects. - London: Routledge

KRÄTKE, S. (1995): Stadt - Raum - Ökonomie: Einführung in aktuelle Problemfelder der Stadtökonomie und Wirtschaftsgeographie. - = Stadtforschung aktuell 53, Basel, Boston, Berlin: Birkhäuser.

LAUTENSACH, H. (1933): Wesen und Methoden der geographischen Wissenschaft. - In: KLUTE, F. (Hrsg.): Handbuch der Geographischen Wissenschaft. Allgemeine Geographie. Erster Teil. Physikalische Geographie. - Potsdam: 23-56.

LEE, R. (1990): Regional geography: between scientific theory, ideology and practice (or, What use is regional geography?) - In: JoHnston, R.J., HAuer, J. \& G.A. HOEKVELD (eds.): Regional Geography. Current developments and future prospects. - London: 103-121.

NIR, D. (1990): Region as a Socio-environmental System. An Introduction to a Systemic Regional Geography. $-=$ The GeoJournal Library, Volume 16. Dordrecht, Boston, London: Kluwer Academic Publishers. PIEPER, R. (1987): Region und Regionalismus. Zur Wiederentdeckung einer räumlichen Kategorie in der soziologischen Theorie. - In: Geographische Rundschau 39,10: 534-539.

Plewe, E. (1952): Vom Wesen und von den Methoden der regionalen Geographie. - In: Storkebaum, W. (Hrsg.) (1975): Zum Gegenstand und zur Methode der Geographie. $-=$ Wege der Forschung LVIII, Darmstadt: 82-110.

PoHL, J. (1986): Geographie als hermeneutische Wissenschaft. Ein Rekonstruktionsversuch. - Kallmünz/ Regensburg: Lassleben.

Popp, H. (1983): Geographische Landeskunde - was heißt das eigentlich? - In: Berichte zur deutschen Landeskunde 56: 17-38.

Priebs, A. (1998): Neubau der Region. - In: von Bandener, S., Nullmeier, F. \& G. Wewer (Hrsg.): Handbuch zur Verwaltungsreform. - Opladen: 122131. 
PuduP, M.B. (1988): Arguments within regional geography. - In: Progress in Human Geography 12.3: 369390.

RAFFESTIN, C. (1982): Remarques sur les notions d'espace, de territoire et de territorialité. - In: Espaces et Sociétés 41: 167-171.

SAYER, A. (1989): The «new» regional geography and the problems of narrative. - In: Environment and Planning D: Society and Space 7: 253-276.

SwYNGEDOUw, E.A. (1989): The Heart of the Place: The Resurrection of Locality in an Age of Hyperspace. - In: Geografiska Annaler 71B: 31-42.

VAN DER WUSTEN, H. (1998): Editorial: Globalization in geography. - In: GeoJournal 45.1-2: 1-3.

VILleneuve, P. (1986): Les théories sur la région: polarisation et capillarité. - In: DE KONINCK, R. \& L. LANDRY (ed.): Les genres de vie urbains: essais exploratoires. - Québec: 17-33.

Weber, M. (1973.5): Asketischer Protestantismus und kapitalistischer Geist. - In: WeBER, M. (Hrsg.): Soziologie - universalgeschichtliche Analysen - Politik. With an introduction by E. BAUMGARTEN. Edited by J. WINKELMANN (orig. 1905). - Stuttgart: 357-381.

WeHLING, P. (1995): Angewandte Ökosystemforschung. Ein Ansatz zur Integration von Natur- und Sozialwissenschaften? - In: Wechselwirkung 10/95, Aachen: 56-61.

WEICHHART, P. (1994): The human ecological relevance of place identity: action theory, emergence and autopoiesis. - In: ERNSTE, H. (ed.): Pathways to human ecology. From observation to commitment. - Bern: 133-147. WERLEN, B. (1995): Sozialgeographie alltäglicher Regionalisierungen. Band 1: Zur Ontologie von Gesellschaft und Raum. - = Erdkundliches Wissen 116, Stuttgart: Franz Steiner Verlag.

WIRTH, E. (1978): Zur wissenschaftstheoretischen Problematik der Länderkunde. - In: Geographische Zeitschrift 66.4: 241-261.

WirTH, E. (1998): Handlungstheorie als Königsweg einer modernen Regionalen Geographie? Was 30 Jahre Diskussion um die Länderkunde gebracht haben. - In: Geographische Rundschau 51.1: 57-64.

WooD, G. (1996): Regionale Geographie im Umbruch? Ansätze einer sozialwissenschaftlichen «New Regional Geography» im angelsächsischen Sprachraum. - In: Berichte zur deutschen Landeskunde 70.1: 55-72.

Zierhofer, W. (1997): Grundlagen für eine Humangeographie des relationalen Weltbildes. Die sozialwissenschaftliche Bedeutung von Sprachpragmatik, Ökologie und Evolution. - In: Erdkunde 51: 81-99.

\section{Summary: On the Future of Regional Geography}

This contribution discusses possible future prospects of regional geography. This is done against the background of current socio-spatial developments and of various theoretical and conceptional debates as they are taking place mainly in English- and French-speaking countries. By taking central elements of modern conceptions of science as a basis possible regional geographic research issues will be identified which promise to be both academically stimulating and socially relevant. A key concern is to show that regional geography can be regarded a viable research task living up to the standards of modern conceptions of science, thereby casting off the dated yet still lingering image that regional geography is mere description or - worse still environmental determinism.

\section{Zusammenfassung:}

\section{Zukunftsperspektiven der Regionalen Geographie}

Der vorliegende Beitrag erörtert mögliche Zukunftsperspektiven Regionaler Geographie. Die Überlegungen hierzu orientieren sich zum einen an aktuellen sozialräumlichen Entwicklungstendenzen, zum anderen an verschiedenen theoretisch-konzeptionellen Diskussionszusammenhängen, wie sie vor allem im französisch- und englischsprachigen Raum zu beobachten sind. Unter Zugrundelegung zentraler Annahmen moderner Wissenschaftkonzepte sollen solche Fragestellungen Regionaler Geographie aufgezeigt werden, deren Bearbeitung wissenschaftlich fruchtbar und gesellschaftlich relevant erscheinen. Geleitet werden diese Überlegungen von dem Anliegen, Regionale Geographie als leistungsfähige Wissenschaft zu bestimmen.

\section{Résumé :}

Perspectives d'avenir pour la géographie régionale Cet article expose les perspectives d'avenir de la géographie régionale. La réflexion repose d'une part sur les tendances actuelles du développement socio-spatial, d'autre part sur divers débats théoriques et conceptuels qui ont surtout lieu dans les pays francophones et anglophones. En se basant sur les principales hypothèses des concepts scientifiques modernes, l'auteur présente les problématiques de la géographie régionale dont l'étude paraît scientifiquement stimulante et socialement pertinente. Cette réflexion est guidée par la volonté de définir la géographie régionale comme une science fiable et performante.

Dr. Gerald Wood, Fach Geographie im Fachbereich 6 der Gerhard-Mercator-Universität Duisburg, Lotharstr. 1, D-47057 Duisburg.

e-mail: g.wood@uni-duisburg.de

Manuskripteingang/received/rentrée du manuscrit: 7.6.1999

Annahme zum Druck/Accepted for publication/ acceptation à l'impression: 15.11.1999 